\title{
Testing of The Validity of Interactive Learning Module on Creative and Entrepreneurs Learning Products
}

\author{
Rini Sefriani $^{1}$, Indra Wijaya ${ }^{2}$, Menrisal $^{3}$, Muharika Dewi ${ }^{4}$ \\ ${ }^{1}$ Information Engineering Education, Universitas Putra Indonesia YPTK, Indonesia \\ Email: rinisefriani@upiyptk.ac.id \\ ${ }^{2}$ Information Engineering Education, Universitas Putra Indonesia YPTK, Indonesia \\ Email: indra_wijaya@upiyptk.ac.id \\ ${ }^{3}$ Information Engineering Education, Universitas Putra Indonesia YPTK, Indonesia \\ Email: menrisal@gmail.com \\ ${ }^{4}$ Information Engineering Education, Universitas Putra Indonesia YPTK, Indonesia \\ Email: maharikadewi@gmail.com
}

(Received: September-2019; Reviewed: December-2019; Accepted: March-2020; Available online: March 2020; Published: April-2020)

A (1) This is an open access article distributed under the Creative Commons Attribution License CC-BY-NC-4.0 (2020 by author (https://creativecommons.org/licenses/by-nc/4.0/ ).

\begin{abstract}
This study aims to determine the level of validity of Interactive Learning Modules in Creative Product and Entrepreneurship Subjects in Vocational Schools. The method used in this research is the 4-D Research and Development method. The steps of this research and development method are: (1) define, (2) design, (3) develop, and (4) assess. Based on research that has been done, the average value of the validator test assessment of the Creative Learning and Entrepreneurship Interactive learning module is $91.92 \%$, so that the level of validity can be interpreted very validly used. In conclusion, based on the assessment and input from experts that the Interactive Learning Module on the subject of Creative Products and entrepreneurship in High Schools and Vocational Schools is feasible to be used in learning Creative Products and Entrepreneurship in Vocational High Schools.
\end{abstract}

Keywords: Interactive Module, Creative Products and Entrepreneurship, R\&D

\section{INTRODUCTION}

The components in learning are very important to be understood by all teachers and educators. Because it will affect the learning process in the classroom. The learning process runs well and smoothly if the learning component plays a role in accordance with its role. There are five components that are very important in the teaching and learning process, namely objectives, materials, methods, media, and evaluation of learning. This learning component is interrelated with one another and affects one component to another. The selection of one particular teaching method in learning will affect the right type of learning media, without negating three other important aspects namely the objectives, material, and evaluation of learning. In this case, it can be said that one of the main functions of learning media is as a teaching aid that also influences, motivates, conditions, and the learning environment (Satrinawati, 2018). The use of instructional media in the teaching and learning process can arouse new interests and desires, arouse motivation and stimulation of learning activities, and even bring psychological influences on students. The use of instructional media in teaching will greatly assist the effectiveness of the learning process and delivery of messages and content (Sumiharsono, Rudi, 2018). Learning media is the most important thing in the learning process. Learning media can be in the form of print, audio, motion media and 
multimedia in the learning process (Arsyad, 2016). The still limited learning resources and interactive multimedia learning media to support the learning process in the subjects of Creative Products and Entrepreneurship, is the duty of policy makers in schools, especially subject teachers.

This is supported by the lack of learning media, learning resources or interactive learning modules that are in line with the learning objectives of Creative Products and Entrepreneurship. Learning media is an intermediary or aids for teachers and students to establish communication about learning material in class, this statement is supported by Benny A.Pribadi (2017) that the use of a variety of media that is in accordance with its attributes and designed with relevant learning theories and principles will be able to assist teachers in creating effective, efficient, and attractive learning programs.

The existence of interactive learning media is very helpful for teachers and students in the learning process so that learning objectives are achieved, this is in accordance with research conducted by (Wijaya, 2017) which shows an increase in student learning outcomes, interactions when learning and increased student motivation to learn with an interactive medium of learning. This is shown by the increasing atmosphere of the learning process activities in the Middle School and Vocational Schools. This is also evidenced by research conducted by (Setiyadi, 2017) those who say that the existence of a learning module as a learning medium can improve student learning outcomes so that many students get grades above the minimum completeness criteria. The results of research from (A. Anggraini \& Sukardi, 2015) also said that product-based modules are effectively used in the learning of craftsmanship and entrepreneurship on processing materials to improve understanding skills for vocational students. It can be concluded that with the presence of additional learning media able to improve student learning outcomes.

Vocational High School is a type of secondary education that specifically prepares its graduates to become skilled and trained workforce. In addition they are expected to easily adapt to the environment and technological changes and can develop themselves in order to meet the labor market in various sectors that are always developing. According to research that has been done by (Interests, Viewed, Internship,
\& Teachers, 2018) stating that teachers play an important role in entrepreneurial learning so that entrepreneurial learning reaches the targets set. Especially this is in the middle school of the conference. Where Vocational School is an educational institution that has a program where students are required to have an expertise. As is the case in SMK Negeri 8 Padang, one of the Competency Competencies provided is Computer and Network Engineering.

One of the productive subjects in Computer and Network Engineering Skills Competency is Creative Products and Entrepreneurship or PKK. PKK is a subject consisting of theory and practice. Theoretic material is delivered in a conventional manner where the teacher acts as the center of learning, while the student practice class is required to be able to operate the applications used for PKK. Entrepreneurship learning is expected to improve entrepreneurial attitudes, entrepreneurial interest, and learning achievement, but in terms of improving entrepreneurial behavior (Mulyani, 2014).

Creative Product and Entrepreneurship subjects are productive subjects in Vocational High Schools, so the school or in this case subject matter teachers must strive to provide teaching materials or learning resources for students in learning Creative and Entrepreneurship Products in the form of interactive learning modules. With the presence of an interactive learning module it is hoped that a communicative, creative and effective learning process will be created in line with the research conducted by (Sefriani, Rini. Wijaya, 2018)

Indicators of achieving learning objectives are one of them can be seen from student learning outcomes, the reality is found in vocational schools where research is conducted in this case at SMK 8 Padang, there are still many students who score or the results of learning Creative and Entrepreneurship Products are below the class average. This is the reason for subject teachers to present interactive learning modules that are packaged in the form of interactive learning modules. In research (Setiyadi, 2017) also states that the existence of a learning module can improve learning outcomes. According (Darmawan, 2012), interactive multimedia learning can make students actively learn with high motivation because of their interest in a multimedia system that presents the display of text, images, videos, 
sounds, and animations. This statement shows that students can be eager to learn with interactive multimedia because it looks interesting and supports learning. The combination of text, images, video, sound and animation can be a source of learning for students. In line with the research conducted by (Wijaya Indra, 2016).

Interactive learning is an effective way for students to be motivated to always want to learn. In this learning process, students are required to be active and there is feedback from the material that has been delivered by the teacher. The learning media used can provide responses to students interacting with each other (Munir, 2015). Can be in the form of a given score, a picture, positive words like, good, successful, yes, or others. Scoring like this is also found in research conducted by (Sefriani, Rini. Wijaya, 2018). Not much different from the research conducted by (Sefriani \& Veri, 2019) which also presents scoring in learning media that is packaged in the form of mobile learning.

According to Sharon E. Smaldino, etc (2011: 279) a teaching module is a complete teaching unit designed for use by a learner or a small group of learners without a teacher present. The interactive learning media created must meet several criteria in order to be applied while learning, one of which is validation by at least 3 expert validators related to the learning media field. For this reason, the validity of interactive learning modules on the subject of creative and entrepreneurial products is carried out. Creative Products and Entrepreneurship is one of the productive subjects of the Computer and Network Engineering expertise program. Based on the curriculum structure PKK subjects delivered in class XI semester 1 and semester 2 each with 6 class hours. PKK is a new subject that is applied in class XI TKJ SMK N 8 Padang and is a combination of entrepreneurship learning and web programming

\section{METHOD}

This type of research is research and development or commonly referred to as research and development (R\&D), which is a research method used to produce certain products, and test the effectiveness of these products. According to (Sugiyono, 2013) there are ten steps in the research and development methods shown in the following chart.

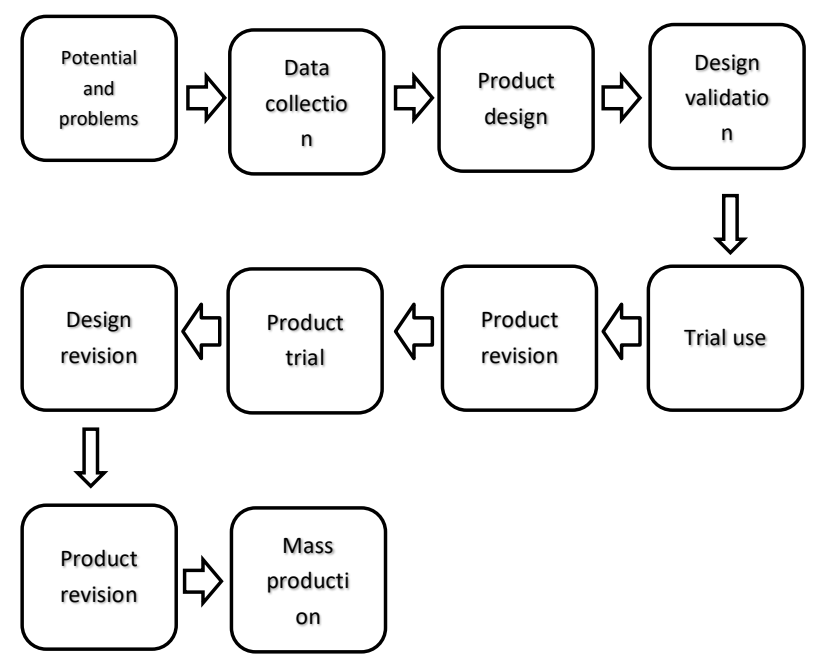

Figure 1. Steps of the R\&D research method

Research and development is a process or steps to develop a new product or improve existing products, which can be accounted for. To be able to produce certain products used research that is needs analysis and to test the effectiveness of these products so that they can be useful in the learning process, research is needed on these products. The research must pass several tests, namely validity, practicality and effectiveness. The module design model used refers to the type of design of four-D models consisting of 4 stages, namely Define, Design, Develop and Dessiminate according to (Thiagarajan, 1974). In this learning module there are several steps that are carried out as an illustration of the making of this learning module. contained in the following figure 2 .

Based on Figure 2, it can be seen that there are three stages of learning module testing that must be done, namely the test of validity, practicality and effectiveness. In this scientific article the focus focuses on the product validity test by experts and continues with the analysis. There are three validators, namely Jhon Veri, S.Kom., MM., M.kom, Mr. Menrisal, S.Pd, M.Pd and Mrs. Desis, S.Pd. 


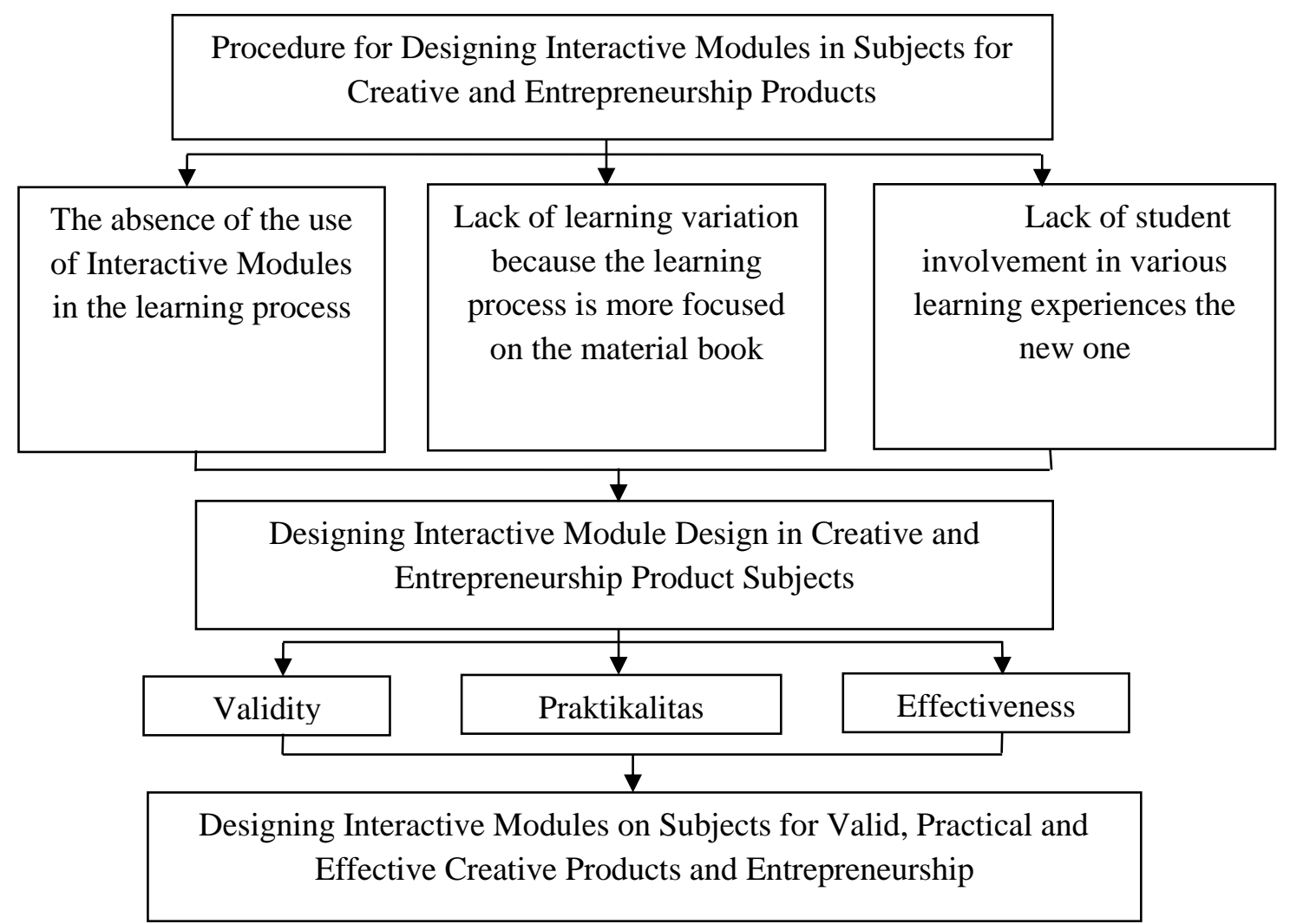

Figure 2. Research flowchart

\section{RESULT AND DISCUSSION}

\section{Result}

Table. 1. Interpretation Criteria for Validation Results

\begin{tabular}{ccc}
\hline Interval Class & $\mathbf{f}_{\mathbf{0}}$ & $\mathbf{\% \mathbf { f } _ { 0 }}$ \\
\hline $88-90$ & 2 & 66,7 \\
$91-93$ & 0 & 0 \\
$94-96$ & 0 & 0 \\
$97-99$ & 1 & 33,3 \\
Total & $\mathbf{3}$ & $\mathbf{1 0 0}$ \\
\hline
\end{tabular}

The average results of the calculation of the value of three validators namely Mr. Jhon Veri, S.Kom., MM., M.kom, Mr. Menrisal, S.Pd, M.Pd and Ms. Desis, S.Pd are 91,917 and see the interpretation criteria table, then it was concluded that the validation from the experts of the Interactive Learning Module for Creative Products and Entrepreneurship was stated to be Very Valid used for Class XI of Computer Network Engineering at SMK N 8 Padang in the academic year 2018/2019.

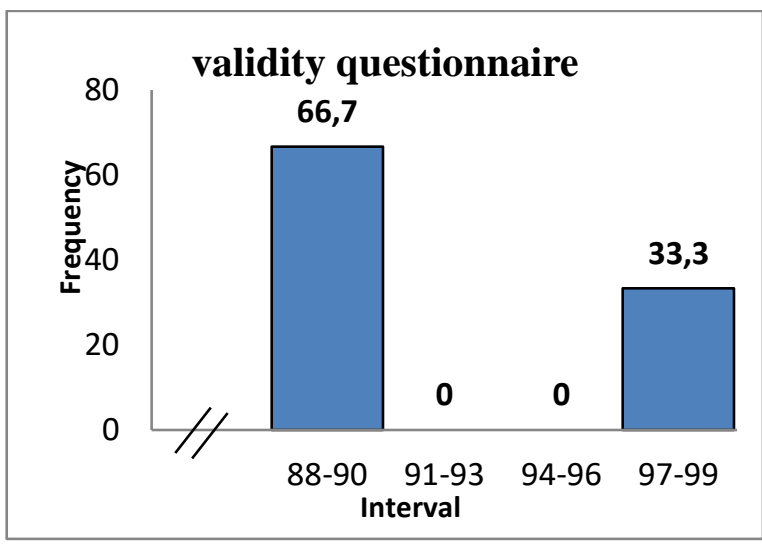

Figure 3. Histogram of validity test

\section{Discussion}

(Agus Fitria et al., 2019) States that to improve students' ability to understand to be able to apply the practice of humanity literacy skills, students must be trained to familiarize students learning using 21 st century learning concepts that are loaded with independence of learning and access to technology that support the improvement of student reasoning due to the support of means the internet as a source of learning by using media teaching modules that have validity. (F. Anggraini, 2016) Teaching materials that support the effectiveness of 
entrepreneurial learning success must be supported by material adjustments related to the changing shape of the digital economic model in accordance with the guidelines for changes in the application of entrepreneurship learning curriculum. The relevance of industry competencies and needs is the basis for innovating entrepreneurship learning.

The Interactive Learning Module for Creative Products and Entrepreneurship is included in computer-based learning, this is in line with what was stated by Wihardjo (2008) states that: "Although the use of computers can improve student learning achievement, but computers cannot replace the role of the teacher as a whole, because of the role the teacher cannot be replaced by any media including computers.

The Interactive Learning Module for Creative Products and Entrepreneurship that has been designed and created allows students to be able to learn independently and more easily. The Interactive Learning Module for Creative Products and Entrepreneurship that has been created has several features which include learning materials that are in accordance with the curriculum, videos, exercises and posttests that function to measure the extent of students' abilities after learning creative and entrepreneurial product materials by using the Interactive Learning Module.

\section{CONCLUSIONS AND SUGGESTIONS}

Based on the description, data analysis, and application development of the Interactive Learning Module it can be concluded that the validity test through an evaluation by the validator on the creation of an Interactive Learning Module for Creative Products and Entrepreneurship is $91.917 \%$, so that the level of validity can be interpreted. Very Valid is used.

\section{REFERENCES}

Agus Fitria, R., Rukun, K., Irfan, D., Dewi, M., Susanti, R., \& Sefriani, R. (2019). New Literacy Oriented Ict Guidance Module Era Of Industrial Revolution 4.0 In Improving Humanity Literacy Of Students. INTERNATIONAL JOURNAL OF SCIENTIFIC \& TECHNOLOGY RESEARCH, 8(09). Retrieved from www.ijstr.org

Anggraini, A., \& Sukardi, S. (2015).
PENGEMBANGAN MODUL PRAKARYA DAN KEWIRAUSAHAAN MATERI PENGOLAHAN BERBASIS PRODUCT ORIENTED BAGI PESERTA DIDIK SMK. Jurnal Pendidikan Vokasi. https://doi.org/10.21831/jpv.v5i3.6484

Anggraini, F. (2016). Pengembangan Modul Pembelajaran Kewirausahaan Model Student Company Di Smk Negeri 1 Godean the Development of a Student Company Model of Entrepreneurial Learning Module At Smk Negeri 1 Godean. 6(1), 24-30. Retrieved from http://journal.uny.ac.id/index.php/jpv

Arsyad, A. (2016). Media Pembelajaran. Jakarta: PT RajaGrafindo Persada.

Darmawan, D. (2012). Inovasi Pendidikan. Bandung: Rosdakarya.

Interests, E., Viewed, S., Internship, F., \& Teachers, R. O. (2018). Entrepreneurship Interests Students Viewed From Internship Experience and Role Of Teachers. 4(3), 179-186.

Mulyani, E. (2014). Pengembangan Model Pembelajaan Berbasis Projek Pendidikan Kewirausahaan Untuk Meningkatkan Sikap, Minat, Perilaku Wirausaha, Dan Prestasi Belajar Siswa SMK. Jurnal Cakrawala Pendidikan. https://doi.org/10.21831/cp.v1i1.1861

Munir. (2015). Multimedia (konsep dan aplikasi dalam pendidikan ). Bandung: Algabeta.

Satrinawati. (2018). Media dan Sumber Belajar. Yogyakarta: Deepublish CV Budi Utama.

Sefriani, Rini. Wijaya, I. (2018). Interactive Multimedia Learning Module Based On Adobe Director On Operation System Course On Vocational High School. INTECOMS, $1(1)$. https://doi.org/https://doi.org/10.31539/inte coms.v1i1.124

Sefriani, R., \& Veri, J. (2019). Pengembangan Mobile Learning Berbasis Client Server Pada Mata Pelajaran Simulasi Digital. KomtekInfo, 5(3), 61-71. https://doi.org/10.29165/komtekinfo.v5i3.1 94 
Setiyadi, M. W. (2017). Pengembangan Modul Pembelajaran Biologi Berbasis Pendekatan Saintifik Untuk Meningkatkan Hasil Belajar Siswa. Journal of Educational Science and Technology (EST), 3(2), 102. https://doi.org/10.26858/est.v3i2.3468

Sugiyono. (2013). Metode Penelitian Kuantitatif, kualitatif dan R \& D. In Bandung: Alfabeta. https://doi.org/10.1017/CBO97811074153 24.004

Sumiharsono, Rudi, D. (2018). Media Pembelajaran. Jawa Timur: Pustaka Abadi.

Thiagarajan, S. (1974). . . Instructional Development for Training Teachers of Exceptional Children A. Sourcebook: Indiana University. Bloomington.
Wijaya, indra \& S. rini. (2017). Interactive Modules Based Adobe Director On Computer Assembling Subjects For Vocational Secondary School. Volt Pendidikan Elektro, 2.

Wijaya Indra, S. R. (2016). Interactive Multimedia CD Design Chemistry Lesson In Concept Training Material and amendment For Class X Vocational High School (SMK). Journal of Dynamics, 1(1). Retrieved from http://ejournal.kopertis10.or.id/index.php/d ynamics/article/view/934 